\title{
A SYSTEM OF JOYFUL COLOUR AND ITS DISRUPTIONS: Architectural Colour in the German Democratic Republic
}

\author{
Dr. Jessica Jenkins \\ Publication Name: Architectural Theory Review, Volume 19, Issue 2, 2014 \\ Publication Date: Feb 27, 2014
}

\begin{abstract}
This paper examines the debates around colour in East German architecture from the mid-1960s to the early 1980s. It traces the gradual relinquishing of the attempt to determine principles for the colouring of socialist architecture based on an idealised conception of socialist society as inducing "joy in life" (Lebensfreude). The relationship to prewar avant garde thinking is examined as problematic, but nonetheless present in the 1960s reconceptions. In the 1970s, colour was discussed not so much as reflecting "joyfulness", but as a means of generating "pleasure" in residential areas. Colour was no longer to serve a projected abstract notion of the condition of socialism, but to relate to the everyday experiences of residents in housing estates and, indeed, to improve these experiences through the "emotional impact" of colour. In the closing phase of the GDR, residents of prefabricated architecture began to introduce their own colours to their loggias, upsetting the predefined colour schemes. By the 1980s, differentiated manifestations of colour in GDR architecture arguably reflected the societal order of the closing years of the Republic-conflicted and fragmented.
\end{abstract}

The association of a monochrome environment with the dull everyday is well established as a cliché of state socialism. The German language has even spawned its own epithet, Alltagsgrau (everyday grey), to describe the confluence of boringness and an absence of material colour, both of which are commonly considered attributes of the former German Democratic Republic (GDR). ${ }^{1}$ Such representations are, predictably, an inversion of the GDR's self-presentation as a society that strove for a systemically induced joy of life 
(Lebensfreude), which, in accordance with the mimetic tradition of Socialist Realism, ought to be reflected in the colourfulness of its material culture.

Focusing on two episodes in the mid-1960s and late 1970s, this paper examines complexities in the attempts to create a workable system of socialist architectural colour by architects stretched between ideological requirements, the demands of economical building production, and the need to accommodate residents' responses to their own housing complexes. This paper argues that the proposals for architectural colour in theory and practice in the GDR were the product of both modernist and Socialist Realist influences, even as Socialist Realist architecture was shaken by the shift to industrialised production methods in the later 1950s.

The polemical harnessing of colour is a persistent if contradictory theme in architecture: combined with structural accents of primary colour, whiteness was seen to represent good hygiene and social reform in the progressive architecture of 1920s Neues Bauen. Le Corbusier construed white in the 1920 s as a carrier of moral order, as absolute, honest, and reliable, and a means to truth, ${ }^{2}$ but black, grey, and white came to stand for luxury in modernism's 1930s Americanised transformation as The International Style. ${ }^{3}$ The German movement for colourful building, which had its beginnings at the turn of the century, ${ }^{4}$ promoted colour as a means to bring cheer to the dilapidated, nineteenth-century stuccoed buildings and was given fresh impetus by Bruno Taut, Adolph Behne, Walter Gropius, and other leading modernists in 1919 in their "Call to Colourful Building" in the 
wake of the destruction of World War I. ${ }^{5}$ The Bund zur Förderung der Farbe um Stadtbild (Association for the Promotion of Colour in the Townscape), formed in 1926, became an umbrella for a collection of agendas, commercial, modernist, and anti-Modern, but fell by 1933 to its inevitable role in the regimentation of colour use to sustain the notion of the German Heimat. ${ }^{6}$

Whilst colour theorists have historically systematised and sought to understand the perception of colour, its cultural associations defy rationalisation. Colour is poised on the edge of reason, bringing with it the same kinds of dangers of excess, inauthenticity, or deception associated with its sister signifier, ornament. As an artificial skin applied to form, applied colour is in itself a form of ornament and, thus, its use in architecture has been inextricably linked to questions of authenticity and social order.

In the GDR, the adoption of Socialist Realism and the campaign against "formalism" from 1950 onwards were accompanied by an official rejection of the avant garde heritage of what was now the GDR. This rejection of early modernism, and in particular of the Bauhaus in the 1950s, with its two major centres in Weimar and Dessau, is well documented. ${ }^{7}$ The later rehabilitation of the Bauhaus, beginning in 1975 , is also well known. ${ }^{8}$ However, the adoption of methods and styles of building which looked much like Western modernism ran concurrently with the accommodation of aspects of Socialist Realism right through the 1960 s and beyond, and was not simply driven by an "instrumentalisation" of modernist heritage to match the needs of production. ${ }^{9}$ East 
German architecture did not ever seek to be "neutral" in form or ideological expression. It was continually charged with the need to carry ideological value, although the way in which this should be achieved was a matter of dispute between architects and critics. The visual and ideological completion of architecture as a socialist manifestation within the urban ensemble through colour, surface finishing, structural ornament, and works of art exercised theorists and practitioners throughout the whole period of systemised architectural production from the latter 1950s to the end of the GDR in 1989.

Socialist Realism was largely defined through the structural referencing of "national tradition", difficult to sustain in serialised building techniques. The departure from Socialist Realism led to a reassessment in the 1960 s of how socialist architecture might be intellectually reconceived. The East German research institute, Bauakademie (Building Academy), sought to form a theoretical basis for the surface colouring of the proliferating prefabricated architecture, which became the standard method for building from the late 1950s.

A reading of the reassessment of architecture in the GDR points to commonalities between the often opposed mindsets of Socialist Realism and a modernist orientated functionalism, both of which had a sustained presence in GDR architectural thinking. The complex of problems encountered-leaving aside the separate questions of supply and choice of pigments in an economy marked by shortages and inefficiencies-reflect the tension in the GDR between the 1950s Socialist Realist conception of architecture as a 
representative expression of ideological order and an emerging functionalist or design oriented understanding of architecture as serving social processes.

Besides referring to national tradition, Socialist Realist architecture was charged with following the tradition of Baukunst (architecture as art). The status of architecture as Baukunst was central to differences between Socialist Realism orientated architects and critics, and the reformers at the Bauakademie led by Swiss architect Hans Schmidt. The definition of architecture as "art" or as an industrial product was crucial: only as art, the Socialist Realist defenders insisted, could architecture carry ideological meaning. The functionalist orientated critics did not describe themselves as such, but they sought to define architecture as a functional product, the socialist content of which was not primarily to be found within the object itself, but within the social relations it served and engendered. In today's terms, the differentiation could be described as that between "art" and "design", where design refers to an intended optimisation of social and spatial relations, whether through artefacts or organisation. The term, Umweltgestaltung (environmental design), was to become central in the reformers' attempt to shake off the orthodoxy of Baukunst.

Disputes over how to define the socialist character of architecture dominated both the historical moments discussed in this paper: at the height of the Wissenschaftlichtechnische Revolution (Scientific Technological Revolution) under SED (Socialist Unity Party) leader Walter Ulbricht in the $1960 \mathrm{~s}^{10}$ and during the acceleration of the production 
of urban complexes under his successor, Erich Honecker, in the 1970 s. ${ }^{11}$ By the end of the 1970s, architects, critics, and local housing authorities found themselves debating an unexpected twist in the use of architectural colour: that of residents' personalisation of their loggias through paint, wallpaper, and accessories. It would be wrong to call this a process of individual differentiation or resistance, since those who undertook the practice were influenced by the trends in the neighbourhood housing blocks, but it could be described as a collective disruption to colour as a system of aesthetic and functional order. Such individualisation arguably signified a democratisation of architecture and a rejection, not only of the role of the architect as artist, but also of the planner of the living complex as a designer able to deliver ideal solutions.

\section{The Significance of Colour and Ornament as a Medium to Accommodate Socialist Realism during the Transition to System-Built Architecture}

From 1950 to 1955, GDR architects were tasked with appropriating "national tradition" in line with the tenets of Socialist Realism. ${ }^{12}$ Colour was present in Socialist Realist discourse through reference to the colours of folk culture as joyful, authentic, and "of the people". In such rhetoric, colour was synonymous with the "joy of life". This connection was made explicit by the first director of the Institute für angewandte Kunst in Berlin, ${ }^{13}$ Walter Heisig, who called in the 1950s for a reawakening of folk art as "the basis of all artistic creation". This applied not only to the development of art production, but also "artistic industrial production". The "new German realistic art" would provide the response to the 
"capitalist un-culture and un-moral" ${ }^{14}$ Brightly coloured patterns on textiles, inspired by appropriate folk art, were an indication of socialist optimism, Heisig claimed. ${ }^{15}$ Decoration, or ornament, had to be present, but it had to be meaningful and ordered within the contours of the form; in other words, ornament had to serve rational ends. Socialist Realism thus shared the moral tenor of modernist rhetoric and similarly strove for "authenticity", "truth", and "rationality". At the same time, Soviet-led Socialist Realism was defined in opposition to American-led Western Modernism, rendering references to the avant garde or the Bauhaus problematic for East German architects between 1950 and $1963 .^{16}$

Khrushchev's 1954 speech to the All Unions Congress of Builders, calling for "better, faster, cheaper" building in the Soviet bloc in which ornament was derided as "perversions", is widely interpreted as signalling the end of Socialist Realism. ${ }^{17}$ However, Khrushchev's speech was a series of exhortations, not a theory. His speech did not represent an embrace of Modernism as a cultural category or the abandonment of Socialist Realism in art or form design, but was, rather, a pragmatic shift to more economical forms of architectural production. However, in the Soviet Union, pragmatism of production did not remove the necessity of theoretical foundations. ${ }^{18}$ Changes were driven by social and economic necessity, but, as Catherine Cooke has argued, were reabsorbed into the Socialist Realist narrative, even if the physical appearance of the new architecture came closer to contemporaneous Modernism in the West. ${ }^{19}$ 
The loss of the palette of architectural forms and detailing derived from the national tradition following Khrushchev's 1954 speech left architects in East Germany with a difficulty as to the socialist character of the new architecture. The president of the Bauakademie, Kurt Liebknecht, argued that GDR architecture was a special case in that it did not suffer from the problem of overbearing decoration, and that the priority was "the struggle of our people towards unity and the maintenance of the national culture", and that "in our conditions the struggle against Formalism [...] is far from over". ${ }^{20}$ For Liebknecht, the proximity to West Germany justified a continued assertion of Socialist Realist difference of architecture and planning.

Uncertain on how to interpret the tenets of Socialist Realism in the context of serially produced buildings, the Bauakademie commissioned research in 1956 on the potential that could be drawn from the Sorbian culture in Hoyerswerda, ${ }^{21}$ the first town to be planned following Khrushchev's speech. ${ }^{22}$ The report found considerable cultural and political value could be extracted from Sorb traditions. The Sorbian craftspeople, "naturally working with joy", had already achieved a form of serial building that offered an ideal model for GDR production. Sorb folk art was mainly dedicated to the ornamentation and enlivening of surfaces: for example, furniture was hand-painted in "blue, wine red, a lot of ivory and a little yellow green brown". ${ }^{23}$ Such decorative treatments could just as well be used in the prefabricated building methods. 
Whilst the ornamentation of concrete slabs at the point of production was indeed technically mastered by 1970 , and occasionally applied, ${ }^{24}$ only the recommendations for folk inspired colouring ${ }^{25}$ were subsequently taken up in Hoyerswerda, where chief architect Richard Paulick applied a Sorbian inspired colour scheme to "Living Complex 1" (1957-1964). For Paulick, a former Bauhaus associate, this reference to Sorb folk traditions in the name of "national tradition" offered a conceptual bridge from Socialist Realist to industrially prefabricated architecture. ${ }^{26}$ Colour in architecture, and in the design of goods, as reflective of the joy of life, offered continuity with the tenets of Socialist Realism. As with folk traditions, idealised as authentic and joyful, the application of colour and ornament to the serially produced object was a means for some by which the same representation of Lebensfreude could be achieved.

The need to address the absence of a coherent theory for the new architecture was established following a crisis in 1959, when bitter exchanges in the professional journal, Deutsche Architektur (German Architecture), and at the Bauakademie Theory Conference (Konferenz über Grundlagen und Aufgaben einer sozialistischen Architekturtheorie) ${ }^{27}$ exposed seemingly irreconcilable differences between the defenders of architecture as art and the proponents of a functionalism oriented architecture. The subsequent Bauakademie research sought to define the appearance and aesthetics of the new architecture and colour was specifically addressed by the head of the Bauakademie Institute for History and Theory (Institut für Geschichte und Theorie), Hans Schmidt. 
Appointed to the Bauakademie in 1956 to oversee the transition to industrialised building, Swiss architect Hans Schmidt (1893-1972) had come to prominence through his radical functionalism in the 1920s. Disillusioned by what he saw as a preoccupation with form in the work of modernist architects in the latter 1920s, he departed from an early radical functionalist stance during his seven-year period in the Soviet Union (1930-1937). Unlike the majority of the German modernist pioneers who set off to realise gigantic architectural projects in the Soviet Union, such as Ernst May's Frankfurt brigade, Schmidt became interested in Socialist Realism and Volkskultur-strictly differentiated from the National Socialist Heimatskunst. Ursula Suter has demonstrated the continuities in Schmidt's architectural-political agenda, as he embraced two apparently opposed cultural approaches, functionalism and historicism. ${ }^{28}$ The confluence of influences in Schmidt's architectural career made him the ideal candidate for the job at the Bauakademie.

Schmidt's early, radical views were expounded in the manifesto-like magazine, $A B C$ :

Beiträge zum Bauen (1924-1928), which he co-published with Mart Stam, El Lissitzky, and Emil Roth. A universally applicable collective model of design was to be characterised by order and Gesetzmässigkeit (a set of laws or principles). The function of colour in this antiart approach was to communicate a system based on essential design elements. Colour should "aim for a direct physiological effect". Red was "fully pulsating", white was "the colour of hygiene and space", and black was the destruction of space. ${ }^{29}$ Thus, colour was assigned perceptual as well as associative functions and essential qualities were assigned to certain colours. Pure colour was more direct in its "effect" than any tint. Black, red, and 
white as the chosen colours corresponded to the anti-art constructivist aesthetic, rather than to the primaries insisted on by the contemporaneous Dutch de Stijl movement. We can trace continuities between Schmidt's early ideas of colour in architecture and urbanism as an anti-aestheticising, ordering principle, and his work in the GDR four decades later.

Schmidt's consistent argument for appropriate colour as subordinate to spatial order was supported with examples of the kind of aesthetic colouring of which he did not approve. At the 1959 Bauakademie Theory Conference organised under his direction, Schmidt criticised the colouring of Richard Paulick's Sorb tradition-inspired housing complex in Hoyerswerda as resulting in "a tectonic which contradicts the facades, through an unharmonious, unsettled effect". ${ }^{30}$

Schmidt also derided the colour in the work of former Bauhaus designer Frank Ehrlich, using it to characterise the Bauhaus and its protagonists as formalists. Likening Ehrlich's colour to an atom bomb, Schmidt described the interior for the Berlin Club for Culture (Klub der Kulturschaffenden), redesigned by Ehrlich, as the "aesthetic sensation of the department store", in which "the spiritual emptiness that capitalism has created in people is filled with an equally empty play with the random, illogical and spontaneous". This kind of architecture was influenced by: the Bauhaus, Le Corbusier, Gropius and Mies van der Rohe, modern music, parallel with abstract painting, into which the architecture of the so called free 
world falls in brilliant technique and in a subjective, lawless play, with the aesthetic pull of colour, light, materials, and so on. ${ }^{31}$

Like Bruno Taut before him, Schmidt was dismissive of the aesthetic styling or colour theories of the painter and decorator and, writing in the trade journal, Farbe und Raum, he warned its readers against arbitrary Buntheit, overly bright and vivid colours, as they could suggest artificiality, excess, and poor taste: whilst "the modern" was absolutely desirable, it had to be ordered and rational, "clean and beautiful".

Schmidt's thinking on the appropriate colour for the new socialist architecture, already expounded at the Bauakademie theory conference, was first elaborated in detail in March 1963 in a special edition of Deutsche Architektur dedicated to the theme of colour. ${ }^{33}$ The journal was for a brief period (1962-1964) edited by Schmidt's junior colleague, the architect and critic, Bruno Flierl, and they collaborated with other colleagues on the reformist research at the Bauakademie. ${ }^{34}$ Schmidt and Flierl aimed to address what they perceived as a lack of system in the colouring of the constructions proliferating in the GDR. Whilst the expanding paint and chemical industry would determine material developments, architectural colour was primarily an "artistic" question. Modern chemistry allowed for new possibilities of architectural colouring and inspiration for this was provided by abstract artists, claimed Schmidt:

The boldness, the primary immediacy, with which we use colour today in graphics, posters, consumer goods and not least in architecture is practically 
unimaginable without the aesthetic preparation of modern painting, in particular abstract artists. ${ }^{35}$

Abstract artists such as Matisse and Braque had delivered "the new beauty of colour", and Mondrian's strong, purist discipline was an example of the use of pure colour in contemporary Dutch and some English architecture. ${ }^{36}$ In raising the spectre of abstract artists who represented the very antithesis of Socialist Realism, Schmidt entered still taboo territory, but, at the same time, he retained the language of Socialist Realism in his reference to beauty. He also carefully described architectural colour, not as a question of art, but as abstract art being able to inspire boldness in colouring. There was no question, in Schmidt's thinking, of architecture returning to the status of an artwork.

In his contribution, Flierl praised examples of architectural colour in Romania, saying that the Romanian architects were carrying out the transition to industrialised building "with great ability and architectural sensitivity". ${ }^{37}$ He was impressed by the lightness and airiness of the commonly chosen tones of pale yellow and turquoise, and the use of colour as an architectonic rather than graphic support, that is, in terms of volume rather than surface. This principle was to remain central to both Schmidt's and Flierl's arguments on architectural colour. Flierl concluded that whilst the Romanian colours could not be identified as drawing on any particular tradition, "in almost no other land has the work of the architect been so supported by the population". ${ }^{38}$ 
Schmidt's conception of architectural colour as an "artistic" task, whilst not delivering the task of colour to the artist, equally kept it out of the hands of the professional colour designer. He derided the examples of interior and exterior colour promoted by the journal, Farbe und Raum, as "ornament, as talented as it is pointless". ${ }^{39}$ He also wanted to move away from any approach to colour determined by the insights of science and psychology in terms of health and safety. This was important, said Schmidt, but colour went beyond these practical and functional levels and had to be a medium of artistic expression in architecture. Artistic expression was "an activity which strives for a humanuniversal content, which does not remain stuck in the functional or ornamental". ${ }^{40}$ For Schmidt, architecture clearly still had an artistic purpose in that it was still tasked with delivering ideological value, but this should not be "reduced" to ornament.

Every epoch had a particular palette of colour in architecture which reflected the order and values of the era, Schmidt argued: Baroque in saturated red, yellow, and green, Rococo in soft pastel tones of pink and purple, and the classical era in blue, light ochre, and sea green, but above all white. ${ }^{41}$ If each societal epoch had a colour in architecture which corresponded to the prevailing power relations, then the new socialist era also demanded such an expression:

The function of colour must be to awaken and embody particular sensitivities and feelings of people, which correspond to the nature of socialist society. By this we mean the joy of life, cheerfulness, optimism, but at the same time, clarity, order and the sense of belonging. [...] We have to set this against the 
depressing image [of the past], not so much brightly coloured, but much more the cheerful and spacious city, the new environment of the socialist era. ${ }^{42}$

Whilst colour reflected cheerfulness and optimism, it should also convey clarity and order, in accordance with a disciplined system-a characterisation which corresponded to the model of the joyful, but disciplined, GDR citizen. ${ }^{43}$ Importantly, colours had to be conceived of in totalising schemes for entire building ensembles, for entire living complexes with their schools, kindergartens, sports, cultural, and other public buildings. Bright or dark colours could be used for accenting particularly important buildings, such as institutional buildings, and balconies, or window frames. Residential buildings needed to be in light and natural colours. The Karl Marx Allee buildings in Berlin, which had just been completed at that time, had a light ceramic surface finishing, which Schmidt found appropriate. However, a bright blue kindergarten next to a bright orange kindergarten did not work; in his view, "we think these colors are much too artificial and should be avoided" $^{44}$

Schmidt's conception of architectural colour as a means to awaken and embody the "joy of life" was akin to that of Bruno Taut in the 1920s. As with Taut, only certain colours would engender such feelings, and a cacophony of bright colour could have the reverse effect. Schmidt's conception differed from some of Taut's ideas in that colour could not be an autonomous architectural medium. Colour for the sake of colour (Selbstzweck) was, in the Socialist Realist thinking to which Schmidt referred, and which still dominated in the 
GDR, no better than form for the sake of form (the maligned formalism). Schmidt was careful not to return architecture to its status of a work of art.

The wider political moment of 1962-1963 was one of Cold War instability in the wake of the Cuba Missile Crisis. This undoubtedly drove the political authorities in the GDR to retreat to an orthodoxy, which had an impact on developments in architecture. This reassertion of orthodoxy, just as the Socialist Realist prescription appeared to be relaxing, is familiar to historians of GDR design through the notorious "tubular vases" controversy, which ensued following the selection of unadorned, streamlined designed objects by the modernism oriented designer, Horst Michel, for the fifth Dresden Art Exhibition of 1962. Michel was accused in Neues Deutschland of regressing into Western forms even as socialist life had advanced. ${ }^{45}$ This is understood as an attempt by the old guard to reign in a creeping modernism.

Schmidt and Flierl were nonetheless confident enough at this time to promote an idea of the built environment which viewed it in a positive way as manufacturable along the same principles as industrial design (Industrielle Formgebung). Schmidt even used the fifth Dresden Art Exhibition to push his ideas forward and was emboldened to make a direct comparison between the thinking and production basis of industrial design with that of serialised architecture. Speaking to architecture students at the TU Dresden in November $1962,{ }^{46}$ he delivered a damning assessment of the Neues Deutschland report on the design exhibits at the fifth Art Exhibition, arguing that industrial design, like architecture, 
should be conclusively removed from the domain of art, and that most of the objects on display were applied arts and "had nothing to do with industrial design". ${ }^{47}$

Schmidt and Flierl's confidence that architecture could be firmly placed within the domain of design, rather than as a form of art, was to prove premature. At a closed meeting, the seventh Plenum (Plenartagung), "Ideological Questions of Architecture and Urbanism”, held at the Bauakademie on 12 July 1963, Gerhard Kosel, Liebknecht's successor as president of the Bauakademie (1961-1965), gathered senior architects and called for ideological clarity "in our own ranks". ${ }^{48}$ The March 1963 "colour issue" of Deutsche Architektur was singled out for criticism, among other things for Flierl's implication that conditions for architects in Romania might be better than in the GDR. All the invited architects had to undertake "self criticism"; Schmidt, however, was not one of those summoned, possibly due to his "guest" status in the GDR. The architectural historian Kurt Junghanns' positive assessments of the reformist architecture of the 1920s were judged to be misplaced for their implication that this was "the germ of socialist architecture". ${ }^{49}$ One of the party loyal architects criticised, Martin Wimmer, has described this event as a symbolic massacre of the young by the Moscow trained old guard. ${ }^{50}$

Whilst Schmidt was not one of those hauled in to undertake self-criticism, it was clear that he was mindful of this change in atmosphere as he went on to elaborate his ideas on architectural colour in a much longer paper presented at the ninth meeting of the Bauakademie later in 1963. References to abstract art were dropped in favour of the safer 
territory of folk art. ${ }^{51}$ Prefacing his remarks with Karl Marx's description of the sense of colour as "the most popular form of aesthetic awareness", ${ }^{52}$ Schmidt claimed, "Colour plays such a big role in folk art, and in all epochs where the art is trying to appeal to the masses the form is supported by colour". ${ }^{53}$

Schmidt offered some general guidelines for determining appropriate and inappropriate colour. Blue had a "questionable psychological effect", but could work with a "strongly contrasting white". Green was also difficult, but, as in the examples of the Leningrad Winter Palace and Bavarian farmers' houses, which used a blue-green "that does not occur in nature", this could be effective, especially when contrasted with the necessary white. In one case, there was a plan "to plaster the side of a pavilion and the facade of a high-rise in an anthracite colour. This would hardly have met the need for optimism and joy of life [...]. Generally it is safe to say that grey, while not to the same extent as black, creates an impression of joylessness" ${ }^{54}$ Schmidt praised the use of light tones in the third and fourth living complexes of Hoyerswerda, which met the requirement of a "cheerful, optimistic foundation".

Schmidt's 1963 paper was as Socialist Realist as it was modernist. His repeated references to colour supporting the joyfulness of life, and the importance of closeness to the people through folk references, were typically Socialist Realist as well as sharing the populism of the early twentieth century campaigners for the colourful town and Bruno Taut's campaign for colourful repainting in Magdeburg during 1921-1924. At the same time, 
Schmidt's insistence on the logic of colour in supporting volume was closer to the functionalist thinking of Neues Bauen. He was not dogmatic in his recommendation of hues, but the preference for lightness and space, perhaps with coloured accents, reflected the modernist ideal of spacious, clean, and hygienic architecture and towns. The use of colour as a means of coding in the city was already present in his own 1926 writing for $A B C$. Like Taut, he was suspicious of the work of the painter-decorator and cautious about the usefulness of colour theory.

Following the shock of the seventh Plenum, Schmidt also sought to re-embed the notion of beauty within the new architecture, claiming that Socialist Realism had retrieved the idea of "beauty" as a desirable principle. Addressing the question, "What is Beauty in Architecture?", ${ }^{55}$ Schmidt argued that socialist architecture still relied on logic and order, for which "Soviet theory offered basic definitions: there are those which can immediately be related to beauty, such as order, clarity, simplicity, economy (...) but these certainly do not include everything that socialist architecture can and must express of greatness, humanity, and joy of life" ${ }^{56}$

Schmidt's ideals for evolving a socialist colour tradition were limited by the realities of budgets and production schedules, and the small circulation of the theoretical publications of the Bauakademie. Reflecting on Schmidt's achievements in 1993, Bruno Flierl wrote that "whilst Schmidt brought architecture closer to industrial building, if more on a theoretical level than a practical one, he did not succeed at all in persuading building 
engineers, technologists and economists of the significance of architectural quality in building production" ${ }^{57}$

In 1967, Schmidt and his team of researchers at the Bauakademie published Contributions to Architectural Theory, ${ }^{58}$ the aim of which was to firmly locate architecture as a societal task, notwithstanding its potentially artistic characteristics. Schmidt's contribution on the role of colour in Contributions had none of the polemical drive of the 1963 publications and he conceded that those proposals had been barely effective in practice. The physiological impact and spatially ordering function of colour were affirmed, but the function of colour as a systemic expression of the joyfulness of socialist society was not mentioned. A comparison of the two texts suggests that Schmidt had again adapted to and taken a lead in a new political Geist, where it was no longer necessary to insist on the significance of historical and folk references, nor to assume a popular interest "of the people" as a basis for socialist architecture.

A number of inconsistencies in Schmidt's arguments point to the balancing act necessary to accommodate both the ideological demands of Socialist Realism and the scientific technological conditions of the 1960s, including the influence of new sciences such as psychology and sociology. Colour should not be populist or sentimental, but it was the most popular form of aesthetic awareness and could learn from folk traditions; architecture was not art, but colouring of architecture was a form of art and should be undertaken by an artist; colouring should not be determined by colour psychology, but, at 
the same time, socialist colour should engender and reflect the joy of life. Schmidt's enduring argument, which he shared with Flierl, was that colour and the spatial arrangements of architecture should offer clarity and order and that colour should always support the volume and never counter it. All these ideals were predicated on the a priori one that the socialist society could be supported and realised through a universal model planned by architectural experts.

Schmidt expressed a disdain for the approach of the "colour designer", rather than that of the artist or architect, but the profession, learnt at the Fachhochschule für Angewandte Kunst (School of Applied Arts) in Heiligendamm or Potsdam, was to acquire increasing significance in the planning of urban complexes as housing production was hugely accelerated in the 1970 s under Honecker's housing programme. Schmidt left the GDR to retire in his native Basel in 1969, but, through his work, he had established a reconception of architecture as the product of societal processes, which itself raised the profile of the design professions. As the concept of "complex environmental design" emerged under the influence of Bruno Flierl in the 1970s, not only colour designers, but also lighting, landscape, and graphic designers were to play a role in the artistic conception of new urban complexes. The colour question was to take a controversial and unexpected turn, but it would not be addressed again in the increasingly arid pages of Deutsche Architektur. The work of Flierl and his close colleagues found a new forum in the Zentral Arbeitsgruppe für Architektur und Kunst (ZAG, the Central Working Group of Architects and Artists) ${ }^{59}$ and through the influence of the maligned painters and decorators' journal, Farbe und Raum. 


\section{The Colour Debate in the 1970s}

Our building stretches far into the future, and architects and town planners, together with artists, landscape and colour designers, have great responsibility to create attractive residential areas that make our people happy. Building Minister, Wolfgang Junker, 6th Building Conference, 1975

Farbe und Raum was less ideologically laden and, thus, less closely monitored by Party authorities than Deutsche Architektur. Much of the journal was concerned with technical questions, such as the durability of new products developed by the paint and chemicals industry. The return to a conservationist agenda for colour also offered secure employment in the restoration of historic city centres according to original colour plans.

Erich Honecker's push to "solve the housing question" by $1990^{60}$ once more raised interest in the emotional impact of colour, particularly its potential for breaking up what was increasingly acknowledged as the monotony of urban housing and thereby improving the emotional well-being of the population. "The happiness of the people" was officially

declared as the first aim of the Party in $1971 .{ }^{61}$ In architecture, colour was called upon not simply to reflect but to engender happiness in socialism. In 1975, architectural theorist Werner Rietdorf urged better colour in housing:

We are at the beginning of a period of housing construction on a scale not seen before. It is important to develop our arguments because colour is becoming 
so important for the support of the wellbeing and happiness of people in the housing complexes. ${ }^{62}$

Competitions were set for the best solutions. The winning complexes of Farbe '75 (Colour '75) did not follow the gentle colouring with structural accents proposed by Schmidt. First prize was awarded to vividly coloured residential complexes, comprising a total of 11,000 apartments, in Magdeburg-Nord, where bright blue, yellow, purple, and orange were applied as surface coating and coloured tiling. According to the planning collective under the direction of chief architect Hans Schroth, the "normal user" did not notice the architectural details so much as the "total emotional value":

To counteract the rigidity of the architecture and bring a cheerful, positive mood into the complex, a range of three dimensional details were introduced and colour was given a primary role. Purist and aesthetic ideas which may have given a better formal aesthetic foundation were accorded less importance as they would have reduced the emotional effect. ${ }^{63}$

If pleasure in the environment was to be invoked as an aim of socialist design, then it had a different quality to the concept of Lebensfreude, or "joy in life", which represented, as David Crowley and Susan Reid have put it, "a kind of abstracted, disembodied higher 64 goal", which demanded self-denial in the present with the promise of a better future. At the same time, the pleasure that may have been invoked by colour was not conceived of as an individual or niche experience, or a relief from the pressures of everyday life, but as a collective experience. 
Whilst Farbe und Raum carried remarkable examples of colour design, it seems not all the complexes had the desired effect of satisfying the residents: by the mid-1970s, the biggest challenge to the systematised planning of architectural colour was the residents' own embellishments of their loggias, not only with brightly coloured paint, but with kitsch objects such as deer antlers or wagon wheels, and even with wallpaper. ${ }^{65}$ The residents' personalisations of their loggias were determined by personal taste, individual artistic expressions, and the materials at hand, forming a spontaneous, haphazard artwork.

These activities provoked strong reactions from architects. Bernhard Geyer of the Bund der Architekten der DDR (Association of GDR Architects) stated:

There is an evident necessity for a clear, complete societal development, particularly in the application of colours on surfaces. We can no longer, and no longer wish to, accept as "harmless" [...] what is going on [...]. We should be led by the aim to find an artistic formal language appropriate for our MarxistLeninist world view.... ${ }^{66}$

The loggia painting controversy ran on for several years and, by the late 1970s, entered the institutional discourses. Influenced by Bruno Flierl, architect Wolfgang Kil took up the editorship of Farbe und Raum from 1978 to 1982 and used it to foster the idea of experiment in both the prefabricated architecture of the living complexes and the neglected historical architecture of the city centres. Arguing for opportunities to make mistakes and the freedom not to plan and design, he presented colourful gable murals 
from Kosalin, Poland, to his readers, arguing that there was a pleasure in playful abstraction and bright colours, in using irony in a pleasing way. ${ }^{67}$

Kil's arguments and examples provoked a furious response from some of his readership, including Gerd Zeugner, author of a textbook on the principles of colour theory, ${ }^{68}$ for whom the examples broke "the basic rules of decorative design on buildings" and 69

provided evidence of "the demolition of the architectural form".

Another reader was concerned about the creeping individualism evident in the painting of the loggias:

The individuality of residents who are really socialist (and not just described as such) should be reflected in the entire urban unity (...) Every developed individuality has its specific function in the community. If this strays into individualism, it can lead to a break down of communality. ${ }^{70}$

The universalising approach to colour in architecture receded as planning collectives and citizens' initiatives sought innovative ways of introducing visual differentiation and individualisation. ${ }^{71}$ By the 1980 s, the intentions of planners and local councils were less characterised by idealism and more by assimilation of the behaviours of residents. Kil suggested to me that the municipal councils "would not have dared" to intervene-it was important not to provoke residents into more serious expressions of rebellion. ${ }^{72}$ 
At the ZAG professional working group 1979 meeting in Gera, which took colour as its central theme, the contradictions and difficulties of finding principles for the application of colour were discussed at length. The contradictions between the GDR's hybrid cultural traditions and the limitations of economically driven housing production were laid bare. ${ }^{73}$ Bruno Flierl, by then a senior and well-respected figure, under whose influence the ZAG had developed as a space for critical discourse, was highly critical of the colour and ornament of the Magdeburg-Nord and Rostock-Schmarl complexes, which he claimed had become independent of form (verselbständigt). Jürgen Deutler, a leading architect of one of the Rostock collectives, who designed eye-popping slabs composed of white plaster quarter forms and integrated bricks in Rostock-Schmarl, defended the architecture in the name of functional orientation, meeting psychological needs ("perhaps there is a yearning for kitsch and nostalgia"), and for its aesthetic and harmonious colour and ornament, which referred to Gothic tradition and relationship to the landscape. ${ }^{74}$ For Deutler, however, the ultimate justification was its popularity with the residents. Flierl admitted to personally rather liking the controversial slabs in Rostock-Schmarl, but was hinting at something much more fundamental: a failure of architecture. "A5 "Archigrafik", as he called it, represented "the helpless attempt by architects, in their impotence to make any progress on the substance of the building in a good functional-aesthetic sense, to try, nonetheless, to achieve something human". ${ }^{76}$

For Flierl, the argument had come full circle: once proposed as a means to faithfully reflect the joyfulness of socialist society, and as a tectonic support which would help achieve 
order in the urban space, colour was again being used as a means of disguise. For Deutler and others, colour and ornament applied to architecture were a means of helping residents forge an identification with their lived environment.

Colour divided architectural opinion, but, at the same time, such divisions were a reflection of an arguably more diverse-or more fragmented-GDR at the beginning of its final decade, one in which differences were increasingly voiced. Both Flierl and Kil used arguments in the 1979 Gera colour seminar as a means to critique architectural practice in the GDR and implicitly, as architecture stood as a metaphor for the very foundation and success of state socialism, of the state itself.

\section{Epilogue}

As the GDR approached its terminus in the 1980s, architectural colour was primarily a means of satisfying the desire for the personalisation of the public face of the home as well as a cache-misère for the disintegrating building substance in old city centres. Architectural colour in the GDR was, arguably, societally determined, but this was by no means the socialist colour culture which Schmidt had projected.

By the late 1970s, a more liberal publishing industry allowed for books and articles on Neues Bauen, Le Corbusier, the Bauhaus, Hannes Meyer and Walter Gropius, Victor Vassarely, Bridget Riley, and Rolf Erskine. Bruno Taut's work was acknowledged through 
the ongoing research of Kurt Junghanns, one of the conveners of the first architectural theory conference in $1959 .^{77}$ The irony was that such ideas were by then of little relevance to architectural practice. The tendencies towards personalised expression, on the basis of individual or local collective initiatives, stood in direct opposition to notions of a socially determined and expertly planned universal approach to colour.

Colour in architecture served a range of architectural and political purposes in the GDR. It was conceived by Hans Schmidt as a foil to modernist formalism, as a means of expressing social order, and as granting artistic value to industrially produced architecture. His work bridged Socialist Realist and Modernist discourses through references to both the historicising and expressive value and the ordering functions of architectural colour. As innovation in socially functional and aesthetically well-conceived new architecture gradually surrendered to the constraints imposed by the tempo of building production during the 1970s, colour took on a new function, which referred back to the claims of 1920s colour campaigners, as a support to an emotional attachment to the lived environment. In the final phase, characterised by a fragmentation of purpose in architectural thinking, colour served to define pockets of individualisation, which, in turn, served as a tool for political critique. Far from colourless, most of the architecture of the GDR was coloured and colour-conscious, and its significance accompanied the entire development of the Republic's architectural history.

\section{Notes}


${ }^{1}$ Walter Ulbricht, "The Five Year Plan and the Perspective of the Peoples Economy”, in Minutes of the III Party Congress of the SED, 20-24 July 1950. Band I Berlin (East) 1951, 67: "Resolution of the Central Committee of the SED against Formalism", March 1951. The resolution marked the beginning of a campaign against all forms of art which were not Socialist Realist and the end of the attempts between 1946 and 1950 to create a functionally oriented, socialist architecture. Explorations in expressionism in painting were also curtailed from this date. The rhetorical demonisation of early Modernism and the Bauhaus lasted, however, just two to three years, but was replaced by an uncertainty amongst architects on how to absorb these traditions.

${ }^{2}$ Ralph Stern, "Defining Shades: weiße und moderne Architektur”, in Klaus Jan Philipp and Max Stemshorn (eds), Die Farbe Weiß. Farbenrausch und Farbverzicht in der Architektur, Berlin: Gebr. Mann, 2003, 70-98. Stern draws on Le Corbusier, L'Art décoratif d'aujourd'hui (1925) and Quand les cathédrale étaient blanches (1937).

${ }^{3}$ The definition of The International Style, adapted from early Modernism, was famously set out, free of any socially reforming associations, in the 1932 MoMa exhibition in New York, "The International Style", curated by Henry-Russell Hitchcock and Philip Johnson. ${ }^{4}$ Calls for colourful building "in our grey times" were made as early as 1901, by Fritz Schumacher, "Farbige Architektur", Der Kunstwart, 20, no. 2 (1901), 297-302. See Martina Düttmann, Friedrich Schmuck, and Johannes Uhl (eds), Farbe Im Stadtbild: Handbuch in 6 Teilen Für Architekten, Bauherren, Farbgestalter, Für Stadtbewohner Und Betrachter, Berlin: Archibook, 1980, 10-11.

${ }^{5}$ Bruno Taut, “Aufruf zum farbigen Bauen!”, Die Bauwelt: Zeitschrift für das gesamte Bauwesen, 38 (18 September 1919). Its signatories proposed, "In the place of the dirty grey house, let us finally have again the blue, red, yellow, green, black and white house in plain, bright tones".

${ }^{6}$ Die Farbige Stadt, 11, (1932), cited by Düttmann, Farbe Im Stadtbild, 27.

${ }^{7}$ Simone Hain, "ABC und DDR. Drei Versuche, Avantgarde mit Sozialismus in Deutschland zu verbinden", in Günter Feist, Eckhardt Gillen, and Beatrice Vierneisel (eds), Kunstdokumentation 1945-1990 SBZ/DDR. Aufsätze. Berichte. Materialien, Cologne: 
DuMont, 1996, 430-477; “The Bauhaus in Cold War Germany”, in Kathleen JamesChakraborty (ed.), Bauhaus Culture: From Weimar to the Cold War, Minneapolis: University of Minnesota, 2006, 177-180.

${ }^{8}$ One of the best accounts is by Wolfgang Thöner, an actor in this history: Wolfgang Thöner, "From an 'Alien, Hostile Phenomenon' to the 'Poetry of the Future': On the Bauhaus Reception in East Germany, 1945-70”, GHI Bulletin Supplement 2 (2005), 115137.

${ }^{9}$ See, for example, Paul Betts, "The Bauhaus in the former German Democratic Republic_-between Formalism and Pragmatism”, in Jeannine Fiedler (ed.), Bauhaus, Bauhaus, Cologne: Könemann, 2000, 48. Rainer Wick frames the late (from 1976) Bauhaus reception in the GDR as "the political instrumentalisation of history" and "historical justification of 'real socialism"”: Rainer K. Wick, "Notizen zur deutschdeutschen Bauhausrezeption nach 1945", Wissenschaftliche Zeitschrift der Hochschule für Architektur und Bauwesen, WZHAB, 38 (1992), 269-276.

${ }^{10}$ The "Wissenschaftlich-technische Revolution" of the later 1960s developed from the economic reforms of the June 1963 New Economic Policy [NÖP], and marked the increased importance of science in political and economic policy, to include previously considered bourgeois sciences such as psychology, sociology, and the then newly fashionable cybernetics. See Hubert Latko, "Wissenschaftlich-technische Revolution: Akzente des Konzepts in Wissenschaft und Ideologie der DDR", in Utopie Kreativ, Berlin: 1966, 35-50.

11 The ambition to "solve the housing problem by 1990" started with half a million new homes to be built between 1971 and 1974: Directive of the VIII Party Congress on the development of the People's Economy of the GDR from 1971-1975, reproduced in Neues Deutschland, 23 June 1971.

12 This was set out at the opening of the Deutsche Bauakademie in 1951 by SED leader Walter Ulbricht. Das Nationale Aufbauwerk und die Aufgaben der Deutschen Architekur, Berlin: Amt für Information der Regierung der Deutschen Demokratischen Republik, 1951. 
13 "The Institute for the Applied Arts". After 1962, the Institute had a series of nominations, all of which reflected the orientation to form design and industry, and away from crafts.

${ }^{14}$ Walter Heisig, Volkskunst in der Sowjetunion, Berlin: Institut für angewandte Kunst, $1952,7,17$.

${ }^{15}$ Walter Heisig, "Zu aktuellen Fragen der angewandten Kunst in Industrie und Handwerk", speech to a seminar for the designers of industrial products (Tagung der Entwerfer für Industieerzeugnisse) in the Deutsche Akademie der Künste, Berlin, 20 January $1953,7$.

${ }^{16}$ The rejection of the avant garde and the Bauhaus in the early GDR is well documented in scholarship. See, for example, Simone Hain, “ABC und DDR, Drei Versuche, Avant Garde mit Sozialismus in Deutschland zu Verbinden”, in Günter Feist, Eckhard Gillen, and Beatrice Vierneisel (eds), Kunstdokumentation SBZ/DDR 1945-1990: Aufsätze, Berichte, Materialien, Cologne: DuMont, 1996; Greg Castillo, “The Bauhaus in Cold War Germany", in Kathleen James-Chakraborty (ed.), Bauhaus Culture, From Weimar to the Cold War, Minneapolis: University of Minnesota Press, 2006, 177-180. In 1963, the Institut für angewandte Kunst in Berlin published L. Pazitnov's Das schöpferische Erbe des Bauhauses, 1919-1933, translated from Russian by Ina Friedenthal, which opened the way for East German evaluations of the Bauhaus.

${ }^{17}$ Nikita Krushchev, "Build Better, Cheaper and Faster", speech given to the All Union Conference of Building Specialists of the USSR in Moscow, 7 December 1954, reproduced in Andreas Schätzke, Zwischen Bauhaus und Stalinallee: Architekturdiskussion im östlichen Deutschland 1945-1955, Braunschweig: Vieweg, 1991, 159.

${ }^{18}$ Catherine Cooke offers an extensive discussion of the significance of Khruschev's speech for theorists and practitioners in the Soviet Union. Catherine Cooke (with Susan E. Reid), "Modernity and Realism: Architectural Relations in the Cold War", in Susan Emily Reid and Rosalind P. Blakesley (eds), Russian Art and the West: A Century of Dialogue in Painting, Architecture, and the Decorative Arts, DeKalb: Northern Illinois University Press, 2007, 183-186.

${ }^{19}$ Catherine Cooke (with Susan E. Reid), "Modernity and Realism”. 
${ }^{20}$ Kurt Liebknecht, X. Plenartagung of the Deutsche Bauakademie, reprinted in Neues Deutschland, 11 February 1955, 4.

${ }^{21}$ Hoyerswerda is situated in the traditionally Sorbian Lausitz region.

${ }^{22}$ G. Blume, “Ausarbeitung über sorbische Kunst zur Gestaltung der Großplattenbauweise in Hoyerswerda", report submitted on 27 January 1956, Bundesarchiv, Deutsche Bauakademie, Forschungsinstitut für Architektur und Wohnungsbau, DH 2/23646. See also Werner Durth, Jörn Düwel, and Niels Gutschow, Ostkreuz, Architektur und Städtebau der $D D R, 2$ vols, Frankfurt on Main: Campus Verlag, 1999, 491-492.

${ }^{23}$ Blume, “Ausarbeitung über sorbische Kunst”.

${ }^{24}$ Research led by the Hochschule der Künste, Dresden, implemented ornamental patterning at the slab production site and applied it, for example, at the Bezirksparteischule, M. J. Kalinin, Cottbus, Brandenburg. Heinz Kästner, "Industrielle Bauproduktion Ohne Monotonie", Deutsche Architektur, 10, (1973), 612-619.

${ }^{25}$ Ornament was also present in the 1955-1956 complexes, but it was not folk inspired: the themes developed by the local design collective "neue form" were abstract or referred to fairy tales, flora and fauna, and mining.

26 "Konferenz über Grundlagen und Aufgaben einer sozialistischen Architekturtheorie" ("Conference on the Fundamentals and Tasks of a Socialist Architecture Theory"), Referat Paulick, BArch, DH2/21201.

27 "Konferenz über Grundlagen und Aufgaben einer sozialistischen Architekturtheorie" ("Conference on the Fundamentals and Tasks of a Socialist Architecture Theory") of the Deutsche Bauakademie, 1959, Bundesarchiv, Berlin, DH2/21201.

${ }^{28}$ Ursula Suter and Hans Schmidt, "Form als soziale Bedeutungsträgerin”, in Ursula Suter and Bruno Flierl (eds), Hans Schmidt, 1893-1972: Architekt in Basel, Moskau, Berlin-Ost, Zürich: GTA, 1993, 27-52.

${ }^{29}$ Mart Stam, Hans Schmidt, El Lissitzky, and Emil Roth, ABC Beiträge zum Bauen, 1, Series 1, 1924.

${ }^{30}$ Schmidt, “Konferenz über Grundlagen...” Bundesarchiv, DH2/21201, 16.

${ }^{31}$ Hermann Exner, "Zusammenklang der Elemente”, Neues Deutschland, 10 May 1958, 9. 
32

"Farbe - ja, aber richtig — auch in Berlin", Farbe und Raum, 11 (1959), 4. The article is signed only "Schmidt", but is almost definitely from Hans Schmidt, who consistently attacked what he saw as colour for the sake of colour, especially if reminiscent of Bauhaus or Modernist aesthetics: "We must remember, that every facade is part of our city image, and we are working towards making Berlin a clean and beautiful city".

${ }^{33}$ Schmidt, "Farbe in Architektur und Städtebau", Deutsche Architektur, 3 (1961), $157-$ 161.

${ }^{34}$ Bruno Flierl, architect and critic, who, on completion of his architecture studies, moved from West Berlin to the East in 1948, describes Schmidt as his mentor.

${ }^{35}$ Schmidt, "Farbe in Architektur und Städtebau", 157.

${ }^{36}$ Schmidt, "Farbe in Architektur und Städtebau", 157.

${ }^{37}$ Bruno Flierl, “Architektur und Farbe in Rümanien”, Deutsche Architektur, 3 (1963), 172.

${ }^{38}$ Flierl, "Architektur und Farbe in Rümanien, 172.

${ }^{39}$ Schmidt, "Farbe in Architektur und Städtebau", 158.

${ }^{40}$ Schmidt, "Farbe in Architektur und Städtebau", 157.

${ }^{41}$ Schmidt, "Farbe in Architektur und Städtebau", 158.

42 Schmidt, "Farbe in Architektur und Städtebau", 158.

${ }^{43}$ Schmidt, "Farbe in Architektur und Städtebau", 158.

${ }^{44}$ Schmidt, "Farbe in Architektur und Städtebau", 158.

${ }^{45}$ The second "formalism debate" was triggered by an article in the SED Party newspaper, Neues Deutschland: Karl-Heinz Hagen, "Hinter dem Leben Zurück: Bemerkungen zur 'Industrielle Formgebung' auf der V. Deutschen Kunstausstellung”, 4 October 1962, 273. The title means approximately "Falling behind Life", meaning that socialist life was advancing whilst design had fallen behind (falling into Western forms). A full account of events is given in Hein Koster, "Schmerzliche Ankunft in der Moderne. Industriedesign auf der V. Deutschen Kunstausstellung”, in Neue Gesellschaft fur Bildende Kunst (ed.), Wunderwirtschaft. DDR-Konsumkultur in den 60er Jahren. Cologne: Neue Gesellschaft für Bildende Kunst, 1996, 96-103. 
${ }^{46}$ Hans Schmidt, "Kunsthandwerk und Industrieform” [Applied Arts and Industrial Form]. The paper was partially reproduced in DA 3/63, 178-180.

${ }^{47}$ Schmidt wanted to clearly differentiate between applied arts (kunsthandwerk) and industrial design (formgestaltung): Schmidt, "Kunsthandwerk und Industrieform", 180. ${ }^{48}$ Seventh Plenartagung, closed meeting: "Ideologische Fragen des Städtebaus und der Architektur”, Deutsche Bauakademie, Berlin, 12 July 1963, 6.

49 "Ideologische Fragen des Städtebaus und der Architektur", 6.

${ }^{50}$ See Wimmer in conversation with Simone Hain: Simone Hain, "Hans Schmidt in der DDR: Annährungen aus historischer Sicht”, in Ursula Suter, Simone Hain and Bruno Flierl (eds), Hans Schmidt, 1893-1972: Architekt in Basel, Moskau, Berlin-Ost, Zürich: gta Verlag, 1993, 91, note 20.

${ }^{51}$ Hans Schmidt, Die Farbe als künstlerischen Mittel des Ausdrucks in der Architektur und im Städtebau; Arbeitsmaterial [Colour as an Artistic Medium of Expression in Architecture and Urbanism], Arbeitsmaterial für die 9 Plenartagung der Deutschen Bauakademie, Berlin: Dt. Bauinformation bei der Dt. Bauakademie, 1963.

${ }^{52}$ Marx-Engels, Works, Berlin, <Publisher>: 1961, Band 13, 130; quoted by Schmidt, Schmidt, Die Farbe als künstlerischen Mittel, 6.

${ }^{53}$ Schmidt, Die Farbe als künstlerischen Mittel, 6.

${ }^{54}$ Schmidt,Die Farbe als künstlerischen Mittel, 9.

${ }^{56}$ Schmidt, "Was ist Schönheit in die Architektur"

${ }^{57}$ Bruno Flierl, "Hans Schmidt in der DDR: Reflexionen eines Mitarbeiters", in Ursula Suter, Simone Hain and Bruno Flierl (eds), Hans Schmidt, 1893-1972: Architekt in Basel, Moskau, Berlin-Ost, Zürich: gta Verlag, 1993, 77-79.

${ }^{58}$ Hans Schmidt, Bruno Flierl, Herbert Ricjen, Alfred Schwandt, Kurt Wilde and Gerd Zeuchner, Beträge zur Architekturtheoretische Forschung: Diskussionsmaterial [Contributions to Architectural Theory: Research Discussion Material], Berlin: Institut für Städtebau und Architektur der Deutschen Bauakademie, 1967. See Bruno Flierl, "Hans Schmidt in der DDR". 
${ }^{59}$ The body was formed in 1968 as a working group between the architects' and artists' unions, the Bund Deutscher Architekten (BdA) and the Verband Bildender Künstler (VBKD and, after 1971, the VBK DDR); it lasted until 1990.

${ }^{60}$ Erich Honecker effectively replaced Walter Ulbricht in 1971, two years before the latter's death. The commitment to "solve the housing problem by 1990 " was made by Honecker as the party's new first secretary in his announcement of the "Unity of economic and social policy", a key reorientation of party priorities made at the VIII Party Congress that year.

${ }^{61}$ For Honecker, the rhetorical emphasis was shifted from science and technological advance to the well-being and happiness of people: "We know only one aim: that the whole politics of our Party penetrates to do everything for the well being of our people, for the happiness of the people, for the interests of the working class, and all working people. That is the meaning of Socialism". Gerhard Krenz, "VIII Parteitag der SED: Alles für das Wohl der Menschen", Architektur der DDR, (1971), 453.

${ }^{62}$ Werner Rietdorf, "Farbgestaltung in komplexen Wohnungsbau”, Farbe und Raum, $12 / 75,8-12$.

63 "Farbgestaltung des 10 geschossigen Wohnungsbaus in Magdeburg Nord", Farbe und Raum, 10/75, 12. Chefarchitekt Hans Schroth. Städtebauliche Direktive Büro des Stadtarchitekten Magdeburg. Gestalterkollektiv des VEB wohnungskombinat Magdeburg, Lothar Ferchland, Peter Gurr and Wulf Rensky.

64

David Crowley and Susan E. Reid, Pleasures in Socialism: Leisure and Luxury in the Bloc, Illinois: Northwestern University Press, 2010, Introduction.

${ }^{65}$ The city architect of Dresden, Dr Michalk, reported in 1976 of loggias adorned with "brick imitation wallpaper, wagon wheels or deer antlers". "Make our city more beautiful through beautiful balconies”, Sächsische Zeitung, Dresden, 15 September 1976. These developments were debated by architects at the ZAG [Central Working Group for Architecture and Art] seminar, "Farbe in der Stadt", Gera, 15-16 November 1979. ${ }^{66}$ Farbe und Raum, 10/75, 6-7.

${ }^{67}$ Wolfgang Kil, "Wände und Bilder”, Farbe und Raum, 5 (1978), 12-14. 
${ }^{68}$ Gerhard Zeugner was author of a textbook on the principles of colour theory:

Farbenlehre für Maler, Berlin: Verlag für Bauwesen, 1963.

69

G. Zeugner, "Letter to the Editor", Farbe und Raum, 9/78.

${ }^{70}$ Klaus Rudolf, “Leserpost” [Readers' Letters], Farbe und Raum, 2/80.

${ }^{71}$ For example, the patterned prefabricated slabs in Rostock Schmarl developed by Jurgen

Deutler and Peter Baumbach, and the personalised and tenants' gardens which allowed for expressions of kitsch, and artist actions initiated in Wolfen Nord: Wolfgang Kil, paper entitled "Transport von Heimat_-Aus dem Dorf nach Wolfen-Nord" at "Hier entsteht", 24 June 2003, organised by the Kulturstiftung des Bundes.

${ }^{72}$ Wolfgang Kil, interviewed by the author in his home in Berlin-Prenzlauerberg, Berlin. October 2011.

${ }^{73}$ The papers are reproduced in edited form in Architektur und Bildende Kunst: Farbe in die Stadt, Berlin: VdBK, 1979.

${ }^{74}$ Jürgen Deutler, Bundesarchiv, ZAG Seminar "Farbe”, Bundesarchiv, 15/563, 33.

${ }^{75}$ Flierl's own sense of impotence as an architectural critic in the face of the building industry is apparent in his comments at the Gera meeting: ZAG Seminar "Farbe", Bundesarchiv, 15/563, 81-85.

${ }^{76}$ Flierl, ZAG Seminar "Farbe", Bundesarchiv, 15/563, 82.

${ }^{77}$ Kurt Junghanns was able to publish an extensive monograph on Bruno Taut in 1970. Bruno Taut, 1880-1938, Berlin: Henschel, 1970. It was also published in West Berlin in 1983 by the Elefanten Press. 